\title{
Clinical-epidemiological profile of acute appendicitis: retrospective analysis of 638 cases
}

\section{Perfil clínico-epidemiológico da apendicite aguda: análise retrospectiva de 638 casos}

Amanda Pereira lima²; Felipe José Vieira ${ }^{1,2}$; Gabriela Procópio de Moraes Oliveira ${ }^{2}$; Plínio dos Santos Ramos²; Marielle Elisa Avelino²; Felipe Garcia Prado²; Gilson Salomão Júnior ${ }^{1}$; Francisco Campos Silva ${ }^{1}$; João Vicente Linhares Rodrigues².

\section{A B S T R A C T}

\begin{abstract}
Objective: to describe the clinical and epidemiological profile of acute appendicitis (AA) of the patients treated at a referral center in the Juiz de Fora macro-region, Minas Gerais State, Brazil. Methods: we conducted a retrospective, observational study in the Dr. Mozart Geraldo TeixeiraEmergency Hospital. We selected 638 patients diagnosed with AA, and analyzed the variables gender, age, evolutionary phase, length of hospital stay, pathological diagnosis, use of antibiotics, use of drains, complications and mortality. Results: AA was more prevalent in young adults (19-44 years) and males (65.20\%). The mean hospital stay was seven days and phase II was the most prevalent. We found the histopathological diagnosis of primary tumor of the appendix in six patients (0.94\%), adenocarcinoma being the most common histologic type (66.7\%). Regarding the use of antibiotics, 196 patients underwent antibiotic prophylaxis and 306 received antibiotic therapy. Eighty-one patients used some kind of drain, for an average of 4.8 days. Seventeen patients died (2.67\%), predominantly males (70.59\%), with mean age of 38.47 years. Conclusion: AA has a higher prevalence in males and young adults. The length of stay is directly associated with the evolutionary phase. The most common complication is infection of the surgical site. Mortality in our service is still high when compared with developed centers.
\end{abstract}

Keywords: Appendicitis. General Surgery. Abdomen, Acute.

\section{INTRODUCTION}

A cute appendicitis (AA) is the leading cause of surgical acute abdomen worldwide, with a prevalence of approximately $7 \%$ of the population ${ }^{1-4}$. It has a peak incidence between 10-14 years in females and 15-19 in males ${ }^{2}$. Appendectomy is the treatment of choice. Besides allowing definitive diagnosis, it also significantly reduces the risk of complications such as perforation, sepsis and death. The most important causal factor of AA appears to be the development of luminal obstruction, whose etiology is associated with age - lymphoid hyperplasia is the most common factor found in patients younger than 20 years, while the obstruction by a fecalith is more common in the elderly ${ }^{4}$.

The classification of the disease according to stage of evolution is important to assess severity and prognosis, as well as allowing the development of therapeutic management protocols and research ${ }^{5}$. Surgical treatment consists of appendix removal using open technique, described by surgery McBurney in 1894, or by laparoscopic appendectomy, described in 1983 by Semm .

Faced with the high prevalence of AA and the possible complications of this clinical picture, the aim of this study was to describe the clinical and epidemiological profile of AA patients at a reference center of Juiz de Fora macro-region, Minas Gerais State, Brazil.

\section{METHODS}

This was a retrospective, observational study, carried out in the Dr. Geraldo Teixeira Mozart Emergency Hospital, in the city of Juiz de Fora, State of Minas Gerais. After approval by the institution Ethics in Research

1 - Dr. Mozart Geraldo Teixeira Emergency Hospital, Juiz de Fora, MG, Brazil. 2 - Faculty of Medical Sciences and Health, Juiz de Fora (SUPREME), Juiz de Fora, MG, Brazil. 
Committee (protocol 1424169), we analyzed medical records of all patients hospitalized for acute abdomen $(\mathrm{n}=$ 1048) from January 2009 to January 2014. Of these, we selected only patients diagnosed with AA $(n=638)$. We excluded cases with insufficient clinical data.

The variables obtained through the patient records were gender, age, evolutionary phase, length of stay, pathological diagnosis, use of antibiotics, use of drain, complications and mortality. The evolutionary phase was rated from 0 to IV: phase 0 - normal appendix; phase I - appendix hyperemia and edema; phase II - appendix with fibrinous exudate; phase III - appendix with necrosis and abscess; and phase IV - perforated appendicitis. We stratified the phases in complicated appendicitis (III and IV) and non-complicated ones (I and II).

Initially, we tested the normality (Kolmogorov-Smirnov) and homoscedasticity of the distribution (Hartley test), validating the use of parametric statistics. We used the Student's t-test to compare the average length of hospitalization between genders, between patients who used and who did not use drains, and between patients undergoing antibiotic prophylaxis. We used a simple ANOVA to check the length of stay associated with disease phase. We adopted the chi-square test to compare the disease phase by gender and mortality by gender. We considered the significance level of $p<0.05$, and used the statistical software SPSS version 20.0 (SPSS, (hicago, USA) for data analysis.

\section{RESULTS}

Of the 1,048 patients diagnosed with acute abdomen, 638 (60.88\%) had AA, representing the leading cause of acute abdomen in the service. The average age was 32 years and there was a prevalence in males (65.20\%). The disease was more prevalent in young

Table 1. Prevalence of acute appendicitis according to age group.

\begin{tabular}{lccc}
\hline Age Group & Classification & $\mathrm{n}$ & $\%$ \\
\hline $0-18$ & Child & 117 & 18.33 \\
$19-44$ & Young Adult & 383 & 60.03 \\
$45-64$ & Adult & 119 & $18.65 \%$ \\
$65-96$ & Elderly & 19 & $2.97 \%$ \\
\hline
\end{tabular}

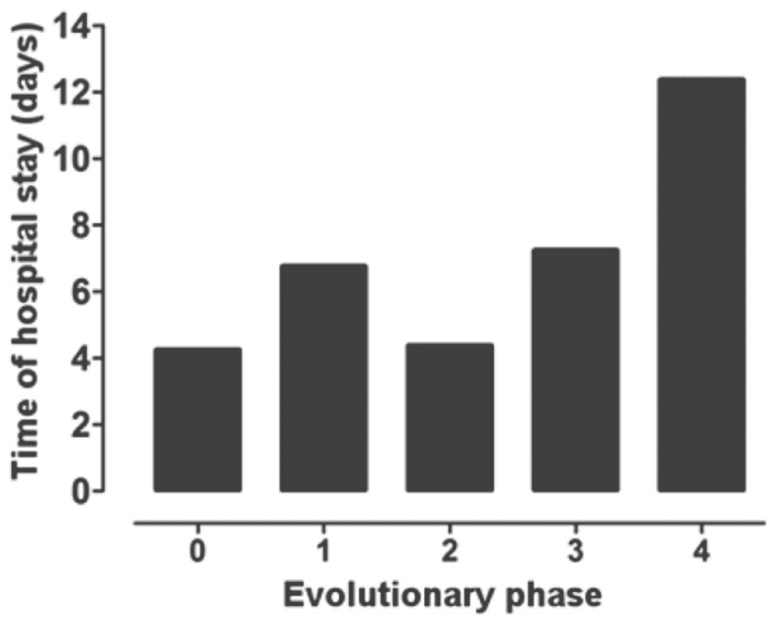

Figure 1. Length of hospital stay in days, according to the acute appendicitis evolutionary phase.

adults (19-44 years), representing $60.03 \%$ of the cases (Table 1), and less common in the elderly (2.97\%). The average length of stay was 7.03 days, 6.77 for men and 7.56 days for women, with no significant difference seen between genders $(p=0.554)$.

Of the patients undergoing appendectomy, $98.75 \%$ had $A$ A. Of patients who underwent incidental appendectomy, 75\% were female and a complicated ovarian cyst was the predominant cause in these patients. In males, the causes were Amyand hernia and adenocarcinoma of the appendix.

Regarding the evolutionary phases, the most frequent was phase II, with $34.30 \%$ (Table 2). Of the patients diagnosed at stage IV, the majority were men (65.8\%). Hospitalization was longer in phase IV, with an average of 12.37 days (Figure 1), with significant differences between stage I and stage IV ( $p=0.001)$.

Of all the pathology results, six $(0.94 \%)$ had a diagnosis of primary tumor of the appendix, of which adenocarcinoma was the most frequent $(66.7 \%)$. The other histological types were squamous cell carcinoma and gastrointestinal stromal tumor (GIST). In addition, the pathological examination diagnose one case of parasitic infestation as AA etiology.

We observed the use of drains in 81 patients, for an average of 4.8 days. There was a higher hospital stay in this group, 10.37 days, compared with those who did not use drains, though without significant difference $(p=0.43)$. 
Table 2. Classification and prevalence of appendicitis according to the evolutionary phase.

\begin{tabular}{llccc}
\hline Phase & \multicolumn{1}{c}{ Definition } & N & $\%$ & \\
\hline O & Normal Appendix & 4 & $0.60 \%$ & \\
I & Appendix with hyperemia and edema & 142 & $22.30 \%$ & NON-COMPLICATED \\
II & Appendix with fibrinous exudate & 219 & $34.30 \%$ & \\
III & Appendix with necrosis and abscess & 162 & $25.40 \%$ & COMPLICATED \\
IV & Perforated Appendix & 111 & $17.40 \%$ & \\
\hline
\end{tabular}

As for the use of antibiotics, 196 patients were submitted to antibiotic prophylaxis, and the combination of amoxicillin with clavulanate was the most used (64.29\%). These patients had shorter hospital stay when compared with those who did not undergo prophylaxis with, a significant difference between groups. Antibiotic therapy was performed in 306 patients $(47.97 \%)$, of whom 214 had complicated AA (69.94\%). The most widely used therapy was the combination of metronidazole with another antimicrobial agent $(40.13 \%)$, mainly ciprofloxacin $(32.03 \%)$ and gentamicin (27.35\%).

Of the total sample, 38 patients $(5.96 \%)$ developed complications in the postoperative period, wound infection (52.63\%) and dehiscence wound (26.31\%) being the most frequent. There were also intra-abdominal abscesses, sepsis and fistula.

Considering mortality, 17 patients died $(2.67 \%)$, with predominance of males $(70.59 \%)$. The mean age was 38.47 years, $70.58 \%$ had complicated AA, and $47.06 \%$ received diagnosed at phase IV, there being a direct correlation between the evolutionary phase and death. As for the causes, 53\% were due to septic shock and $47 \%$ to unknown or undetermined causes.

\section{DISCUSSION}

In this study, AA was more prevalent in males, which is consistent with other studies ${ }^{7-9}$. However, the most prevalent age group was 19-44 years, contrasting with epidemiological data showing that the disease is more prevalent in young people aged 10-19 years ${ }^{7,8}$.

We found that only $1.25 \%$ of patients underwent incidental appendectomy, with a higher prev- alence in women, the ovarian cyst being the predominant etiology ${ }^{10}$. Thus, in women with acute abdomen, ultrasound is important for the differential diagnosis of diseases of the female genital system ${ }^{9,10}$. Furthermore, due to the appendix topography, infections of the upper genital tract can lead to "reactive periapendicites", whose main cause is pelvic inflammatory disease (PID) ${ }^{10}$.

Histopathology is a best practice because it allows identifying malignancy in up to $1 \%$ of patients, most often in the form of neuroendocrine tumor, adenocarcinoma or mucinous cystadenoma ${ }^{11}$. In our study, there was no case of neuroendocrine tumor, despite this being considered the most common appendix primary neoplasm, accounting for approximately $32-57 \%$ of tumors of the organ ${ }^{12}$. Adenocarcinoma was the most prevalent tumor in our series; this cancer is rare, accounting for less than $0.5 \%$ of all gastrointestinal tumors and between $4-6 \%$ of tumors of the appendix. In these cases, hemicolectomy must be performed ${ }^{13,14}$.

A study from South Africa evaluated the pathology results of 371 patients who underwent appendectomy and revealed parasitosis as incidental diagnosis in $8.5 \%$ of $\operatorname{cases}^{15}$. In our study, only one patient had AA by parasitic infestation.

Non-complicated AA, when treated with appendectomy compared with treatment with antibiotics, has a lower rate of complications ${ }^{16}$. A systematic review analyzed a number of meta-analyses and concluded that the treatment of AA only with antibiotics should not be routinely recommended. The realization of appendectomy remains the gold standard for AA treatment ${ }^{17}$.

Although antibiotic prophylaxis is common in surgical procedures, the inappropriate use of these drugs 
occurs in $25-50 \%$ of general elective surgeries ${ }^{18-20}$. All patients undergoing appendectomy should receive antibiotics, prophylactic or therapeutic, and these should be started before surgery ${ }^{21}$. When prophylactic, they should be administered in the anesthetic induction. The chosen drug must be active against Gram negative and anaerobic bacteria, and among the latter, specifically, Bacteroides fragilis. A meta-analysis of randomized trials comparing preoperative prophylactic antibiotics with placebo showed a significant reduction of wound infection with the use of any antimicrobial agent ${ }^{22}$. In our study, the combination of amoxicillin with clavulanate was the most used prophylaxis (64.29\%), and patients undergoing antibiotic prophylaxis had shorter hospital stay when compared with those who did not. Therefore, the preoperative use of antibiotics is prudent; however, continued therapy will depend on the operative findings of abscess or perforation ${ }^{23}$.

In a retrospective study that evaluated 107 appendectomy patients in a reference hospital, the most prevalent developmental stages were phases II (27\%) and IV $(27 \%)^{24}$. In our study, phase II was the most prevalent, accounting for $34.30 \%$ of cases.

Unlike uncomplicated AA, the perforated form is associated with a higher chance of postoperative complications such as intra-abdominal abscesses ${ }^{25,26}$. In these cases, drains are widely used by surgeons to avoid the formation of intraabdominal abscesses. One study evaluated 199 patients with complicated AA, of whom 79 used drains and 120 did not: $15 \%$ of patients without peritoneal drainage developed intra-abdominal abscess after appendectomy ${ }^{27}$.

The most common appendectomy postoperative complications are related to the degree of appendiceal inflammation. It is important to take into account the time elapsed from the onset of symptoms and the time of operation ${ }^{23}$. Postoperative complications remain around $10 \%$, the surgical site infection being responsible for one-third of them ${ }^{5,28}$. Infection of the surgical site occurred in $3.45 \%$ of our patients and was the main postoperative complication. Its frequency ranges between $0 \%$ and $15 \%$ for the laparotomic procedure ${ }^{5,29}$.

The hospitalization time also increases with the severity of appendicitis ${ }^{30}$, which we also observed. The mortality in developed centers is low $(0.09 \%$ to $0.24 \%)$. According to the literature, in low- and middle-income countries, mortality varies between $1 \%$ and $4 \%$, being a useful marker of health care quality. In our service, mortality was $2.67 \%$, which demonstrates the close relationship between the socioeconomic status of the country and the quality of health services ${ }^{11}$.

In conclusion, AA showed higher prevalence among males and young adults (19-44 years). Hospitalization time was directly associated with the evolutionary phase and increased with the severity of appendicitis. The most common complication was surgical site infection, corroborating the literature data. Mortality was also high, which shows the need to improve the quality of public health care in Brazil.

\title{
R E S U M O
}

\begin{abstract}
Objetivo: descrever o perfil clinicoepidemiológico da apendicite aguda (AA) dos pacientes atendidos em um centro de referência da macrorregião de Juiz de Fora, MG. Métodos: estudo observacional retrospectivo, realizado no Hospital de Pronto Socorro Dr. Mozart Geraldo Teixeira. Um total de 638 pacientes diagnosticados com AA foram selecionados. As variáveis analisadas foram sexo, idade, fase evolutiva, tempo de internação, diagnóstico anatomopatológico, uso de antibióticos, uso de dreno, complicações e mortalidade. Resultados: a AA foi mais prevalente no adulto jovem (19-44 anos) e no sexo masculino (65,20\%). O tempo médio de internação foi de sete dias e a fase II foi a mais prevalente. O diagnóstico anatomopatológico de tumor primário de apêndice foi realizado em seis pacientes (0,94\%), sendo o adenocarcinoma o tipo histológico mais frequente (66,7\%). Quanto ao uso de antibióticos, 196 pacientes foram submetidos apenas à antiobioticoprofilaxia e 306 receberam antibioticoterapia. Da nossa casuística, 81 pacientes fizeram uso de dreno, cujo tempo de uso foi em média 4,8 dias. Considerando a mortalidade, 17 pacientes morreram (2,67\%), predominando o sexo masculino (70,59\%) e média de idade de 38,47 anos. Conclusão: a AA apresenta maior prevalência no sexo masculino e no adulto jovem. O tempo de internação está diretamente associado à fase evolutiva. A complicação mais comum é a infecção de sítio cirúrgico. A mortalidade em nosso serviço ainda é alta comparada a centros desenvolvidos.
\end{abstract}

Descritores: Apendicite. Cirurgia Geral. Abdome Agudo. 


\section{REFERENCES}

1. Sandell E, Berg M, Sandblom G, Sundman J, Fränneby $U$, Boström L, et al. Surgical decision-making in acute appendicitis. BMC surgery. 2015;15:69.

2. Papandria D, Goldstein SD, Rhee D, Salazar JH, Arlikar J, Gorgy A, et al. Risk of perforation increases with delay in recognition and surgery for acute appendicitis. J Surg Res. 2013;184(2):723-9.

3. Osime OC, Ajayi P. Incidence of negative appendectomy: experience from a company hospital in Nigeria. Cal J Emerg Med. 2005;6(4):69-73.

4. Shogilev DJ, Duus N, Odom SR, Shapiro NI. Diagnosing appendicitis: evidence-based review of the diagnostic approach in 2014. West J Emerg Med. 2014;15(7):859-71.

5. Gomes CA, Nunes TA. Classificação laparoscópica da apendicite aguda. Correlação entre graus da doença e as variávies perioperatórias. Rev Col Bras Cir. 2006;33(5):289-93.

6. Jaschinski T, Mosch C, Eikermann M, Neugebauer EA. Laparoscopic versus open appendectomy in patients with suspected appendicitis: a systematic review of meta-analyses of randomised controlled trials. BMC Gastroenterol. 2015;15:48.

7. Sulu B, Günerhan Y, Palanci Y, Isler B, Ca layan K. Epidemiological and demographic features of appendicitis and influences of several environmental factors. Ulus Travma Acil Cerrahi Derg. 2010;16(1):38-42.

8. Al-Omran M, Mamdani M, McLeod RS. Epidemiologic features of acute appendicitis in Ontario, Canada. Can J Surg. 2003;46(4):263-8.

9. Ximenes AMG, Mello FST, Lima-Júnior ZB, Ferreira CF, Cavalcanti ADF, Dias-Filho AV. Tempo de internação após apendicectomia aberta por três técnicas cirúrgicas diferentes. $A B C D$, arq bras cir dig. 2014;27(3):188-90.

10.Pages-Bouic E, Millet I, Curros-Doyon F, Faget C, Fontaine $\mathrm{M}$, Taourel $\mathrm{P}$. Acute pelvic pain in females in septic and aseptic contexts. Diagn Interv Imaging. 2015;96(10):985-95.

11.Bhangu A, Søreide K, Di Saverio S, Assarsson JH, Drake FT. Acute appendicitis: modern understanding of pathogenesis, diagnosis, and management. Lancet. 2015;386(10000):1278-87.

12.Gu Y, Wang N, Xu H. Carcinoid tumor of the appendix: a case report. Oncol Lett. 2015;9(5):2401-3.

13.Park IJ, Yu CS, Kim HC, Kim JC. Clinical features and prognostic factors in primay adenocarcinoma of the appendix. Korean J Gastroenterol. 2004;43(1):29-34.

14.Guraya SY, Almaramhy HH. Clinicopathological features and the outcome of surgical management for adenocarcinoma of the appendix. World J Gastrointest Surg. 2011;3(1):7-12.

15. Chamisa I. A clinicopathological review of 324 appendices removed for acute appendicitis in Durban, South Africa: a retrospective analysis. Ann R Coll Surg Engl. 2009;91(8):688-92.

16.Kirby A, Hobson RP, Burke D, Cleveland V, Ford G, West RM. Appendicectomy for suspected uncomplicated appendicitis is associated with fewer complications than conservative antibiotic management: a meta-analysis of post-intervention complications. J Infect. 2015;70(2):105-10.

17. Rocha LL, Rossi FM, Pessoa CM, Campos FN, Pires CE, Steinman M. Antibiotics alone versus appendectomy to treat uncomplicated acute appendicitis in adults: what do meta-analyses say? World J Emerg Surg. 2015;10:51.

18.Dellinger EP, Gross PA, Barrett TL, Krause PJ, Martone WJ, McGowan JE Jr, et al. Quality standard for antimicrobial prophylaxis in surgical procedures. Infectious Diseases Society of America. Clin Infect Dis. 1994;18(3):422-7.

19.Gyssens IC, Geerligs IE, Nannini-Bergman MG, Knape JT, Hekster YA, van der Meer JW. Optimizing the timing of antimicrobial prophylaxis in surgery: an intervention study. J Antimicrob Chemother. 1996;38(2):301-8.

20.Dahms RA, Johnson EM, Statz CL, Lee JT, Dunn DL, Beilman GJ. Third-generation cephalosporins and vancomycin as risk factors for postoperative vancomycin-resistant enterococcus infection. Arch Surg. 1998;133(12):1343-6.

21.Kasatpibal N, NØrgaard M, SØrensen HT, SchØnheyder HC, Jamulitrat S, Chongsuvivatwong V. Risk of 
surgical site infection and efficacy of antibiotic prophylaxis: a cohort study of appendectomy patients in Thailand. BMC Infect Dis. 2006;6:111-9.

22.Andersen BR, Kallehave FL, Andersen HK. Antibiotics versus placebo for prevention of postoperative infection after appendicectomy. Cochrane Database Syst Rev. 2005;(3):CD001439.

23. Nutels DBA, Andrade ACG, Rocha AC. Perfil das complicações após apendicectomia em um hospital de emergência. ABCD, arq bras cir dig. 2007;20(3):146-9.

24.Fischer CA, Pinho MSL, Ferreira S, Milani CAC, van Santen CR, Marquardt RA. Apendicite aguda: existe relação entre o grau evolutivo, idade e o tempo de internação? Rev Col Bras Cir. 2005;32(3):136-8.

25.Fraser JD, Aguayo P, Leys CM, Keckler SJ, Newland JG, Sharp SW, et al. A complete course of intravenous antibiotics vs a combination of intravenous and oral antibiotics for perforated appendicitis in children: a prospective, randomized trial. J Pediatr Surg. 2010;45(6):1198-202

26.St Peter SD, Sharp SW, Holcomb GW, 3rd, Ostlie DJ. An evidence-based definition for perforated appendicitis derived from a prospective randomized trial. J
Pediatr Surg. 2008;43(12):2242-5.

27.Beek MA, Jansen TS, Raats JW, Twiss EL, Gobardhan PD, van Rhede van der Kloot EJ. The utility of peritoneal drains in patients with perforated appendicitis. Springerplus. 2015;4:371.

28.Johnson AB, Peetz ME. Laparoscopic appendectomy is an acceptable alternative for the treatment of perforated appendicitis. Surg Endosc. 1998;12(7):940-3.

29. Majewski W. Diagnostic laparoscopy for the acute abdomen and trauma. Surg Endosc. 2000;14(10):930-7.

30.Tsai CC, Lee SY, Huang FC. Laparoscopic versus open appendectomy in the management of all stages of acute appendicitis in children: a retrospective study. Pediatr Neonatol. 2012;53(5):289-94.

Received in: 13/03/2016

Accepted for publication: 21/06/2016

Conflict of interest: none.

Source of funding: none.

\section{Mailing address:}

Amanda Pereira Lima

E-mail: amandapl.md@gmail.com 